DOI: 10.46340/eppd.2021.8.1.11

Tetiana Marchenko

ORCID ID: https://orcid.org/0000-0003-1542-647X

National University "Odesa Law Academy", Ukraine

\title{
THE RIGHT OF THE ACCUSED TO HAVE ADEQUATE TIME AND FACILITIES FOR THE PREPARATION OF HIS / HER DEFENCE IN ECHR'S DECISIONS: THE MAIN CRITERIA TO BE CONSIDERED BY NATIONAL COURTS
}

\begin{abstract}
Almost every trial is permeated with the issue of ensuring the right to defence. In view of this, the issue requires a detailed study of all the elements that this right contains. Article $6(3)$ of the Convention for the Protection of Human Rights and Fundamental Freedoms provides for minimum rights, which are at the same time separate elements of the right to defence, and which must be respected in order to ensure effective defence. This paper concerns the very determination of the essence of one of the guaranteed rights, namely the right of the accused to have adequate time and facilities for the preparation of his / her defence. This right is provided for by Article 6 (3) b of the Convention for the Protection of Human Rights and Fundamental Freedoms. In order to determine the content of this right and the conditions (criteria) under which this right is considered to be respected, it is necessary to analyze the relevant practice of the European Court of Human Rights. This paper reflects the main positions of the European Court of Human Rights regarding the ensuring of the right guaranteed by Article 6 (3) b of the Convention for the Protection of Human Rights and Fundamental Freedoms both in terms of adequacy of time and sufficiency of facilities to prepare a defence position. Thus, the results of this research reflect a list of conditions (criteria), failure of which by the prosecutor's office and the court will lead to a violation of the right of the accused to have adequate time and facilities for the preparation of his / her defence. The research also raises the question of the level of independence of this right and its relationship with other rights guaranteed by Articles 6 (1) and 6 (3) of the Convention for the Protection of Human Rights and Fundamental Freedoms and the principle of equality of arms.

Keywords: adequate time, adequate facilities, right to defence, European Court of Human Rights, the accused, Convention for the Protection of Human Rights and Fundamental Freedoms.
\end{abstract}

\section{Introduction}

National legislation whatever "perfect" it may be, in itself fails to ensure that the rights of suspects and accused are properly respected. The effectiveness of the legal norm depends on its proper application. Therefore, the deep understanding of the legal norm and its correct application by the prosecution and the court makes it possible to guarantee the suspect / the accused observance of their rights. The analysis of relevant decisions of the European Court of Human Rights (hereinafter referred to as ECHR, the Court) makes it possible to single out a guideline on the application of certain provisions of the Convention for the Protection of Human Rights and Fundamental Freedoms (hereinafter referred to as Convention) which are also implemented in national legislation.

The Convention guarantees to the suspect / the accused a number of rights, which are enshrined in Art. 6 (3) and are elements of the right to defence. One of such rights is the right of the accused to have adequate time and facilities for the preparation of his / her defence provided for in paragraph (b) of the Article 6 (3).

This right is enshrined in national legislation of Ukraine, but in practice, there are a number of difficulties with its proper observance. In turn, a comprehensive analysis of the ECHR' decisions provides an understanding of the true meaning of this right and gives and an opportunity to identify a number of conditions (criteria) that must be met for this right to be effectively exercised and in no way unreasonably limited.

Article $6 \S 3$ (b) of the Convention concerns two elements of a proper defence, namely the question of facilities and that of time. This provision implies that the substantive defence activity on the accused's 
behalf may comprise everything which is "necessary" to prepare the trial. The accused must have the opportunity to organise his defence in an appropriate way and without restriction as to the ability to put all relevant defence arguments before the trial court and thus to influence the outcome of the proceedings (Can v. Austria, Commission report, §53; Gregačević v. Croatia, § 51). The issue of adequacy of the time and facilities afforded to an accused must be assessed in the light of the circumstances of each particular case (Iglin v. Ukraine, § 65; Galstyan v. Armenia, § 84). ${ }^{1}$

2. Regarding the Issue of Time. Effect of Lack of Time for Preparation of the Defence Position on the Adequacy of Facilities.

In the case of VYERENTSOV $\boldsymbol{V}$. UKRAINE, the applicant complained that the administrative records had been drawn up only a few hours before the hearing and that he had not been allowed to study any other case file prior to that hearing. It follows from the decision that only a few hours elapsed between the drawing up of the administrative offense report and the examination of the applicant's case. The court, in turn, pointed out that "Even if it is accepted that the applicant's case was not a complex one, the Court doubts that the circumstances in which the applicant's trial was conducted were such as to enable him to familiarise himself properly with and to assess adequately the charge and evidence against him and to develop a viable legal strategy for his defence" 2 .

The Court therefore concluded that the applicant was not given both adequate time and facilities to prepare his defence. Accordingly, the Court pointed to a violation of Art. 6 (1) taken together with Art. 6 (3) $b$ of the Convention. This, in turn, indicates the urgent need to take into account the time needs of the defence to prepare its position by both the prosecution and national judges.

In the case of PÉLISSIER AND SASSI v. FRANCE the Court, in particular, considered the issue regarding the applicants' conviction for an offense different from the primary charge and the use against the first applicant a document, the admissibility of which was subject to appeal.

Examining the circumstances, the Court emphasized that "...in using the right which it unquestionably had to recharacterise facts over which it properly had jurisdiction, the Aix-en-Provence Court of Appeal should have afforded the applicants the possibility of exercising their defence rights on that issue in a practical and effective manner and, in particular, in good time"s. The materials submitted to the Court indicated that the applicants did not have the opportunity to prepare their defence position on the new charge, as they learned about the recharacterisation of the facts only from the decision of the Court of Appeal, and that was too late. Therefore Court concluded that the applicants' right to be informed in detail of the nature and cause of the accusation against them and their right to have adequate time and facilities for the preparation of their defence were infringed. This case also demonstrates that judges when considering cases with similar circumstances (change of charge) should assess the adequacy of the time provided to the defence for additional preparation / adjustment of its position with regard to such changes.

In the case of G.B. v. FRANCE the applicant complained of a violation of Art. 6 (1), in particular the principle of equality of arms, in conjunction with Art. 6 (3) b of the Convention. The complaint contained several aspects, in particular the submission of new documents by the prosecution at the beginning of the trial and, consequently, the lack of time for the applicant and his lawyer to prepare a defence.

However, the Court came to the conclusion, that "it was entirely lawful for the prosecution, at the beginning of the trial, to file new documents relating to the applicant's personality; these were communicated to the defence and subsequently examined adversarially. It also notes that the applicant himself did not criticize the production of those documents in itself. It finds therefore that this did not in itself give rise to any infringement of the principle of equality of arms between the parties" 4 .

This case demonstrates that the nature of the information / document, the fact that the defence is aware of the existence of such a document may affect the court's position on adequacy of time needed for the defence.

\footnotetext{
${ }^{1}$ Council of Europe, European Court of Human Rights (2018). Guide on Article 6 of the European Convention on Human Rights Right to a fair trial (criminal limb), 365-366.

${ }^{2}$ European Court of Human Rights (2013). Vyerentsov v. Ukraine, 20372/11, 76.

$<$ https://www.conjur.com.br/dl/decisao-corte-europeia-ucrania.pdf $>$ (2021, January, 12).

${ }^{3}$ European Court of Human Rights (1999). Pélissier and Sassi v. France, 25444/94, 62

$<$ https://www.legal-tools.org/doc/c7f9e0/pdf/> (2021, January, 12).

${ }^{4}$ European Court of Human Rights (2002). G.B. v. France, 44069/98, 60

$<$ https://cambodia.ohchr.org/sites/default/files/echrsource/G.B.\%20v.\%20France\%20[2\%20Oct\%202001]\%20[EN].pdf $>$ (2021, January, 12).
} 
Case of LAMBIN v. RUSSIA, in particular, concerned the lack of time to study the materials of the case. The Court assessed the circumstances and noted that the applicant had already had the opportunity to examine the case file during the proceedings in 2005, then, after the case was reopened in 2010 , the applicant and his lawyer were given another opportunity to examine the case file.

The applicant and his lawyers had five days to study the six-volume case, which contained about 1,500 pages. According to the records submitted to the Court, they studied between 187 and 413 pages daily. The Court also noted that in the appeal filed in 2010, the applicant had analyzed the case file in detail, referred in detail to all the main evidence, including expert opinions and witness statements, and indicated the exact pages in the case file. Moreover, the lawyers did not object to the adequacy of the time to study the materials, and the applicant, in turn, was not limited in the number and duration of meetings with lawyers (paragraphs 41-45). The Court did not find the violation of the right guaranteed by Article $6 \S \S 1$ and 3 (b) of the Convention ${ }^{1}$.

Several other criteria (conditions) follow from this case, which the Court considers important to take into account in determining the "sufficiency of time", namely, the fact of acquaintance with the case materials during the previous proceedings, acquaintance with the materials by the complainant's lawyers, the way the applicant describes the circumstances in documents, which testify to the applicant's awareness of the details of the case file.

Case of TWALIB v. GREECE concerned, in particular, the lack of time (less than an hour) for the applicant's lawyer, who had been assigned by the trial court during the hearing, to examine the case file. In addition, the applicant was convinced that mentioned lawyer could not properly represent his interests, as he also represented another co-accused whose interests contradicted his own.

Having assessed the circumstances of the case, the court took into account the shortcomings regarding the limited time allowed in the court of first instance and stated that, given the applicant's allegation regarding a conflict of interest between him and his co-accused, the brevity of this period of preparation can hardly be justified by the fact that the lawyer, as a representative of another accused, was well versed in the case file.

At the same time, the Court noted that during the trial in the appellate court where another lawyer represented the applicant, the applicant had challenged his conviction and sentence before a five-judge panel of the Athens Court of Appeal, which was empowered to hear all the facts of the case and issues of law that arose in this case and cancel the contested decision.

The Court noted that the lawyer had not argued during the appeal hearing that a retrial was necessary due to the shortcomings of the applicant's representation at first instance. The Court added that, in any event, the Chamber of the Court of Appeal of Athens, composed of five judges with full powers to consider both factual and legal issues, reached its conclusion upon results of the hearing attended by the applicant and his lawyer. The Court did not find a violation of Art. 6 (1) in conjunction with Art. 6 (3) b of the Convention, stating that the applicant had the opportunity to express an alleged 'inadequacy' during the appellate hearing, and there is no indication that the fairness of the appellate proceedings could have been called into question (para. 42) ${ }^{2}$.

Thus, in assessing the "sufficiency" of time, the Court may take into account, for example, the existence of a conflict of interest between co-accused represented by one counsel, the applicant's statements during both the trial court and the appellate court (or the absence of expected statements). The Court also took into account the possibility for the applicant to raise the issue of violation of his right in the appellate court and the possibility for the appellate court to fix the shortcomings of the trial in the court of first instance.

In the case of GALSTYAN $\boldsymbol{v}$. ARMENIA complainant, in particular, alleged a violation of his right guaranteed by Art. 6 (3) b of the Convention. The Court considered a violation of this rule in conjunction with Article 6 (1) of the Convention. The Court refers to its key decisions, which raised the issue of violation of the right of the accused to have adequate time and facilities to prepare his defence, namely: Can v. Austria, no. 9300/81, Commission's report 12.07.1984, Series A no. 96, § 53; Connolly v. the United Kingdom (dec.), no. 27245/95, 26.06.1996; Mayzit v. Russia, no. 63378/00, § 78, 20.01.2005.

The Court reiterated that the provision of this right contained everything "necessary" to prepare the defence's position for the main proceedings; the accused must be able to organize his defence properly and in the absence of restrictions on the submission of all arguments to the court that may affect the course of the

\footnotetext{
${ }^{1}$ European Court of Human Rights (2018). Lambin v. Russia, 12668/08

$<$ https://www.bailii.org/eu/cases/ECHR/2017/1021.html> (2021, January, 12).

${ }^{2}$ European Court of Human Rights (1998). Twalib v. Greece, 24294/94

$<$ https://www.tandfonline.com/doi/abs/10.1080/13642989808406777?journalCode=fjhr20 > (2021, January, 12).
} 
case. The case concerned the commission of a crime involving minor hooliganism and was considered under an expedited procedure (the statutory term is 1 day).

The Court recalls, however, that the existence and application of expeditious proceedings in criminal matters is not in itself contrary to Article 6 of the Convention as long as they provide the necessary safeguards and guarantees contained therein (para.85).

Having examined the circumstances and national rules, the Court concluded that neither the case file nor the Government's position indicated that the applicant was aware of the possibility of requesting a postponement of the hearing due to insufficient time to prepare his defence. The Government could not convincingly prove that the applicant had unequivocally enjoyed the right, both in law and in practice, to adjourn the hearing for further preparation of his position.

The pre-trial procedure lasted about two hours, which the Government considered sufficient because, according to it, the case was simple, the applicant allegedly withdrew his defence counsel and did not exercise his right to lodge motions and challenges, voluntarily signed a record of an administrative offense.

However, the Court's position on this issue is somewhat different: "the mere fact that the applicant signed a paper in which he stated that he did not wish to have a lawyer and chose to defend himself in person does not mean that he did not need to be afforded adequate time and facilities to prepare himself effectively for trial.

Nor does the fact that the applicant did not lodge any specific motions during the short pre-trial period necessarily imply that no further time was needed for him to be able - in adequate conditions - to properly assess the charge against him and to consider various avenues to defend himself effectively" ${ }^{1}$.

It also follows from the decision that the very fact of signing the record confirmed only the applicant's acquaintance with his rights and the charges against him.

The Court concluded that the right of the accused to sufficient time and facilities to prepare his defence had been violated, together with the more general right guaranteed by Art. 6 (1) of the Convention, giving the following reasons for its decision.

The documents in the case do not clearly show how long the pre-trial procedure lasted, but it lasted no more than a few hours. During this time the applicant was taken to a courtroom or detained at a police station without any contact with the outside world.

Moreover, during this surprisingly short period, investigative actions such as questioning and search were carried out against the applicant. Despite the fact that the case was simple in nature, given the above circumstances, the Court had strong doubts, in particular regarding the sufficiency of time to carry out an adequate assessment of the charges and evidences in the case and to form a viable defence strategy.

In the case of TADEVOSYAN $\boldsymbol{v}$. ARMENIA in almost similar circumstances (non-public hearing, the applicant was held in a cell in the judge's office; the decision was based solely on police materials; the applicant was not allowed to make telephone calls and question witnesses; there was virtually no time to gather evidence and prepare a defence position: the arrest took place at 16:00, and the trial - at 18:00) the Court came to the same conclusions ${ }^{2}$.

Thus, these cases demonstrate that courts must take into account in any case the length of the pre-trial stage, the time between detention and trial, the time to lodge the motion, and the time to question witnesses. Moreover, the mere fact of signing the report on the violation and the refusal from the defence counsel in no way indicates the sufficiency of the time provided to the accused and his / her readiness for the court hearing.

\section{Regarding the Right for Adequate Facilities in the Light of the Right for Effective Defence.}

The "rights of defence", of which Article $6 \S 3$ (b) gives a non-exhaustive list, have been instituted above all to establish equality, as far as possible, between the prosecution and the defence. The facilities which must be granted to the accused are restricted to those which assist or may assist him in the preparation of his defence (Mayzit v. Russia, $\S 79)^{3}$.

In the case of MATTOCCIA v. ITALY applicant raised the issue of violation of Art. 6 (1) in conjunctions with Art. 6 (3) a and 6 (3) b of the Convention.

In the para 61 of the decision Court noted the following: "as concerns the changes in the accusation, including the changes in its "cause", the accused must be duly and fully informed thereof and must

\footnotetext{
${ }^{1}$ European Court of Human Rights (2008). Galstyan v. Armenia, 26986/03, $86<$ https://laweuro.com/?p=985> (2021, January, 12).

${ }^{2}$ European Court of Human Rights (2009). Tadevosyan v. Armenia, 41698/04 <https://sip.lex.pl/orzeczenia-i-pismaurzedowe/orzeczenia-sadow/41698-04-tadevosyan-v-armenia-wyrok-europejskiego-520562115> (2021, January, 12).

${ }^{3}$ Council of Europe, European Court of Human Rights (2018). Guide on Article 6 of the European Convention

on Human Rights Right to a fair trial (criminal limb), 365-366.
} 
be provided with adequate time and facilities to react to them and organise his defence on the basis of any new information or allegation"'.

The Court added, inter alia, that the applicant in the case had not been able and could not have read the materials available to the prosecution, as access to the case file had become possible only after the preliminary investigation had been completed.

In the Court's view, although the applicant might have had timely access to the prosecution's case file, this did not relieve the prosecution of its obligation to inform the accused immediately and in detail of the full content of the charges against him. This duty rests entirely with the prosecutor's office and is not subject to passive performance, providing information without notifying the defence.

The Court noted that in this case the defence encountered exceptional difficulties. The Court found that the information contained in the indictment was completely vague and contradictory as to the details concerning the time and location, which had changed several times during the trial. The Court also mentioned that "in view of the lengthy period that had elapsed between the committal for trial and the trial itself (more than three and a half years) compared to the speed with which the trial was conducted (less than one month), fairness required that the applicant should have been afforded greater opportunity and facilities to defend himself in a practical and effective manner, for example by calling witnesses to establish an alibi" 2 .

The Court found a violation of the applicant's right to detailed information on the nature and cause of the accusation against him and his right to sufficient time and opportunity to prepare his defence.

Thus this decision shows several criteria (conditions) that must be met (taken into account) to ensure "adequacy" of time: awareness of the accused about the full content of the charge, the information on the charges' change, bringing this information by the prosecutor's office to the defence and the time provided for review and preparation of the defence position, access to the materials available to the prosecution, the correlation of time intervals between the moment of materials' submission to the court and the actual consideration of the case and the speed of the trial, the possibility of witnesses' involvement.

In the case of G.B. v. FRANCE, where the applicant complained of a violation of Art. 6 (1), in particular the principle of equality of arms, in conjunction with Art. 6 (3) b of the Convention, the issue of the national court's refusal to obtain an alternative expert opinion was considered.

Thus, the Court, referring to its case-law in paras $64-70$, in particular noted that the mere fact that an expert expressed a different opinion than in his written statement did not in itself infringe the principle of a fair trial, and that the right to a fair trial does not require a national court to appoint another expert at the request of the defence, even if the opinion of the expert appointed by the defence confirms the position of the prosecution. However, in this case, the expert not only expressed a different opinion than that set out in his written report - he completely changed his mind during the same hearing.

The Court also noted that the applicant's application for an alternative opinion followed this "volteface" made by the expert, who quickly reviewed the new evidence (in a quarter of an hour) and took a very unfavorable position towards the applicant. The Court added that, although it was difficult to establish what effect the expert opinion might have on the jury's assessment, the Court considered a high probability that such a sharp turn would inevitably give particular weight to the expert opinion ${ }^{3}$.

In the light of these specific circumstances, the Court considered that the requirements of a fair trial had been violated and the rights of the defence were not respected, that led to violation of the Art. $6(1)$ and 6 (3)b of the Convention.

This case illustrates how even a sharp change in the expert's opinion can affect the accused's right to sufficient facilities to prepare his /her defence.

In the case of HADJIANASTASSIOU v. GREECE the applicant complained about the short procedural time limit for appealing against the decisions of the military courts and the lack of opportunity to get acquainted in time with the content of the court decisions against which he had appealed. Given the inability to determine the grounds on which the military appellate court relied in its judgment, the applicant lodged a complaint alleging that there was no real possibility of detailing his cassation appeal. However, the Court of Cassation left such an application without consideration.

\footnotetext{
${ }^{1}$ European Court of Human Rights (2000). Mattoccia v. Italy, 23969/94, 61

$<$ https://www.menschenrechte.ac.at/orig/00_4/Mattoccia.pdf $>$ (2021, January, 12).

${ }^{2}$ European Court of Human Rights (2002). G.B. v. France, 44069/98, 71

$<$ https://cambodia.ohchr.org/sites/default/files/echrsource/G.B.\%20v.\%20France\%20[2\%20Oct\%202001]\%20[EN].pdf $>$

(2021, January, 12).

${ }^{3}$ Ibid. 
It follows from the Court's decision that the judgment, which was announced by the President of the Courts-Martial Appeal Court, did not contain the information reflected in the record of the hearings and was not based entirely on the same evidence and reasons as the decision of the Permanent Air Force Court. As the applicant received the record of the hearing only after lodging a cassation complaint concerning the violation of procedural law, he did not have the relevant information to specify his complaint. In view of these circumstances, the Court found a violation of Art. 6 (3) b in conjunction with Art. 6 (1) of the Convention ${ }^{1}$.

This decision illustrates that the lack of reasoned justification in the court decision and the short procedural deadlines for filing a cassation appeal are likely to violate the accused's right to a fair trial, especially regarding the right to adequate time and facilities to prepare his / her defence.

In the case of DOMENICHINI v. ITALY the applicant also complained of a violation of Art. 6 (3) b of the Convention.

In this case, the Government was convinced that the fact of opening and reading the relevant letters had in no way adversely affected the applicant's defence preparation since the applicant had always been able to communicate with his lawyers in the visiting room, subject to visual supervision by a warder.

The applicant pointed to the illusory nature of confidentiality as the supervisor had every opportunity to eavesdrop on applicant's conversations with his lawyer. The applicant further alleged that the prison staff had intercepted his letter addressed to a lawyer, the content of which was relevant to the case. The letter was handed over to a lawyer only later, so it lost its importance to the case.

The Court pointed out that there was no need to consider the issue of checks on the applicant's communication with his lawyers. Nevertheless, the Court found a violation of Art. 6 (3) b due to a delay in sending a letter to a lawyer, which significantly affected the defence ${ }^{2}$.

In the case of ABRAMYAN v. RUSSIA the applicant complained on the violation of Article 6 of the Convention in connection with the failure to notify the applicant about the date and place of the hearing by the courts, which resulted in a violation of the principle of equality of arms. The complaint also concerned the reclassification of the offense by the trial court, which prevented the applicant from preparing his defence position properly. In the present case, the Court recalled that the right to be informed of the nature and cause of the accusation should be considered in the light of the accused's right to prepare his defence, guaranteed by Art. 6 (3) b of the Convention.

The Court also recalled that even assuming that the applicant had not clearly expressed in his application his intention to take part in the appeal proceedings, the judicial authorities had to inform the applicant of the hearing in order for the proceedings to be fair. The Court found a violation of the right to defence and the principle of equality of arms.

The circumstances of the case show that the Supreme Court, which had the power to carry out a full review of the case, considered and rejected the applicant's appeal at an oral hearing, having heard the position of the prosecution only. However, the applicant and his lawyer were not present at the hearing that deprived the applicant of the opportunity to exercise his rights of defence in relation to the re-qualified charge in a practical and effective manner. In these circumstances, the Court found a violation of applicant's right ${ }^{3}$.

The decision in this case demonstrates the need to provide the parties with equal opportunities, in particular with regard to personal participation in the court hearing, obtaining information about the date and place of its holding, especially when the prosecution enjoys such a privilege without reasonable justification.

In the case of MOISEYEV v. RUSSIA applicant, referring to Article 6 (3)b and 6 (3)c of the Convention complained about the lack of sufficient facilities to prepare his defence due to limited access to the indictment, case file and personal notes, strictly regulated communication with lawyers and appalling conditions of transportation and detention in court.

In this case, the Court assessed the following issues: the availability of legal aid, the applicant's and his lawyers' access to the case file, and the impact of the applicant's transportation and detention conditions at the court building on his ability to prepare his defence.

\footnotetext{
${ }^{1}$ European Court of Human Rights (1992). Hadjianastassiou v. Greece, 12945/87 <https://sip.lex.pl/orzeczenia-i-pismaurzedowe/orzeczenia-sadow/12945-87-hadjianastassiou-v-grecja-rezolucja-komitetu-521829056> (2021, January, 12).

${ }^{2}$ European Court of Human Rights (1996). Domenichini v. Italy, 15943/90

$<$ https://www.refworld.org/cases,ECHR,3ae6b6d810.html > (2021, January, 12).

${ }^{3}$ European Court of Human Rights (2009). Abramyan v. Russia, 10709/02

$<$ https://hudoc.echr.coe.int/fre\#\{"itemid":["001-155161"]\}> (2021, January, 12).
} 
The Court reminded that the principle of equality of arms requires that each party be given a reasonable opportunity to present its arguments in circumstances which do not place it at a disadvantage vis-à-vis the other party (para 203).

With regard to the restriction on obtaining legal aid, the applicant could contact the defence counsel only with the prior permission of the relevant body in charge of the case. Moreover, each individual meeting between the defence counsel and the applicant required a separate permit, and the lawyers' attempts to prolong such "passes" were unsuccessful. Permission for an unlimited number of meetings was obtained when the decision of the court of the last instance came into force.

It follows from the circumstances of the case that the prosecuting authority had unrestricted access to the applicant, and that communication between the applicant and his lawyers was carried out under the full control of that authority. The Court, in turn, noted that the need to apply for a separate permit for each visit created significant practical difficulties in exercising the right of defence, as it detracted time and effort from pursuing the defence team's substantive mission. The Court was further concerned that this arrangement made the defence dependent on the discretion of the prosecution and its subordination, thus destroying the external manifestations of equality of arms. The prosecution has repeatedly abused its dominant position in this matter, in particular by refusing to accept the defence's request on obtaining permission for an unlimited number of visits (para. 205). The circumstances of the case show that the requirement to obtain a visitation permit not only burdened the defence, but also was deprived of legal grounds.

Thus, the Court noted in paragraph 207 that the control exercised by the prosecution over access to the applicant by his counsel undermined the appearances of a fair trial and the principle of equality of arms ${ }^{1}$.

Thus, in determining the sufficiency of facilities to prepare a defence position, the presence of excessive control by the prosecution in the case of detention should be taken into account, as well as the real possibility of confidential communication with defence counsel without the need for unreasonable additional "passes"(permission).

In the case of $\ddot{O C A L A N} \boldsymbol{v}$. TURKEY the applicant alleged that the trial did not meet the requirements of Article 6 of the Convention. The applicant, in particular, complained of obstacles to communication with his lawyers: his lawyers were not allowed to visit him until ten days after his arrest, and by that time he had already made statements to the court. He also faced difficulties in appointing lawyers of his choice.

His first meeting with lawyers took place in the presence of law enforcement officials. Other meetings with lawyers took place under audio and video control. Therefore, the applicant was convinced that his right to private communication with his lawyers had been completely restricted. After two brief initial visits, contact with his lawyers was limited to two weekly visits of one hour each. The applicant emphasized that his lawyers had not enjoyed the same conditions as the prosecution.

The applicant also complained about limited access to the case file.

In addition, the applicant's lawyers encountered difficulties in reviewing all the case file due to the surprisingly fast-track proceedings. They were given access to the 17,000-page case file just sixteen days before the hearing. Moreover, the defence was deprived of an adequate opportunity to fully analyze the documents due to the above-mentioned restrictions and obstacles regarding communication between defence counsel and the applicant.

The applicant in the case also alleged a violation of the principle of equality of arms, referring in particular to the difficulties that prevented him and his lawyers from having sufficient time for private communication and the real possibility of access to the case file.

In this case the Court came to the conclusion that "the applicant's trial was unfair for the following reasons: he had no assistance from his lawyers during questioning in police custody; he was unable to communicate with his lawyers out of the hearing of third parties; he was unable to gain direct access to the case file until a very late stage in the proceedings; restrictions were imposed on the number and length of his lawyers' visits; and, lastly, his lawyers were given proper access to the case file belatedly. The Court finds that the overall effect of these difficulties taken as a whole so restricted the rights of the defence that the principle of a fair trial, as set out in Article 6, was contravened. There has therefore been a violation of Article $6 \S 1$ of the Convention, taken in conjunction with Article $6 \S 3$ (b) and (c) "' ${ }^{2}$.

\footnotetext{
${ }^{1}$ European Court of Human Rights (2009). Moiseyev v. Russia, 62936/00 <https://sip.lex.pl/orzeczenia-i-pismaurzedowe/orzeczenia-sadow/62936-00-moiseyev-v-rosja-decyzja-europejskiego-520596694> (2021, January, 12).

${ }^{2}$ European Court of Human Rights (2005). Öcalan v. Turkey, 46221/99, 148

$<$ https://hudoc.echr.coe.int/fre\#\{"itemid":["001-69022"]\}> (2021, January, 12).
} 
Thus all these listed aspects together are the conditions that must be met in order to ensure sufficient time and opportunity for the defence to prepare its position.

In the case of ZOON $\boldsymbol{v}$. THE NETHERLANDS the applicant complained of a violation of Art. 6 (1) in conjunction with Art. 6 (3) b of the Convention, which was caused by the inability to obtain a copy of the full decision of the court of first instance at the time when it was deciding on the appeal. In its report of 4 December 1998 the Commission agreed with the applicant that there had been a violation of Art. 6 (1) and Art. 6 (3) $b$ of the Convention. The Government did not agree with this decision. The Court considered two aspects of this issue: the availability of a copy of the written decision at the time when the applicant had to decide whether to challenge the judgment and the availability of the decision only in shortened form.

The applicant alleged that he had not had a copy of the full written decision or the shortened judgment before the deadline for lodging his appeal. No one was provided to the applicant on the day of the judgment. Moreover, the applicant's lawyer was denied a copy of the decision. This was due to the approach of the court regarding the issuance of copies of decisions in writing in the absence of a written statement of the party.

The lawyer, in turn, noted that he was not aware of such a policy of the court, as it had never been made public, and therefore it would be wrong to expect such awareness from members of the Rotterdam Bar Association (paras 33-24). That is, the applicant and his lawyer were deprived of the opportunity to properly understand the grounds on which the court's decision was based and, consequently, to consciously assess the possible outcome of the appeal. In addition, the court did not read the motivating part of the decision. The Court, in turn, noted in paragraph 36 of the decision that the question of the extent to which the court's decision had been read out in public in the presence of the defence remained a moot point. However, it is not disputed that the operative part of the judgment was read out in public in the presence of the applicant's lawyer.

The Government, for their part, argued that the summary judgment was available for review in the regional court's register after it had been made, and that, in accordance with the above-mentioned court policy, a copy would have been provided to the defence if it had requested it in writing. The shortened decision was available for review forty-eight hours after the moment it was made.

In this regard, the Court stated that the applicant was aware of the operative part of the judgment, and that he and his counsel could have taken into account the shortened judgment before the expiry of the fourteen-day appeal period in order to have sufficient time to file the appeal.

Assessing the fact that the decision was available only in shortened form, which, according to the applicant, did not contain enough information for him to make a reasoned decision as to whether to appeal, the Court noted that the defence's position concerned the validity of the summons, the admissibility of the materials submitted by the prosecution, the legality of the method of evidences' obtaining, the qualification of the actions and the application of mitigating circumstances, which in turn were decided in the shortened court decision. The applicant did not object to this.

The Court based its decision on the following. Although the evidence on which the decision was based was not listed in it, the applicant never objected to the actions set out in the decision and never challenged the evidence against him as such. Moreover, the applicant did not state and it did not follow from the case that he was convicted on the basis of evidence which was neither contained in the case file nor presented at the hearing.

The Court took into account, in particular, that in the Netherlands the criminal proceedings on appeal were directed not against the decision of the court of first instance itself, but against the accusation. The appeal procedure, therefore, involves a completely new establishment of facts and reassessment of existing legislation. In the Court's view, the applicant and his counsel were able to make a conscious assessment of the possible outcome of any appeal in the light of the summary judgment and the evidence in the case file ${ }^{1}$.

Thus, in the Court's view, there had been no violation of Art. 6 (1) in conjunction with Art. 6 (3) b of the Convention.

This decision is an excellent illustration of the fact that the Court takes into account all the circumstances of the case together, assessing the real possibility of the defence to commit an action, including assessing the reality of restrictions (obstacles) that could be caused by the court's actions (for example failure to notify of specific procedures for obtaining a copy of the decision or limited time for filing an appeal). The Court also takes into account how closely the procedure in the appellate court

\footnotetext{
${ }^{1}$ European Court of Human Rights (2000). Zoon v. the Netherlands, 29202/95 <https://heinonline.org/HOL/ LandingPage?handle=hein.journals/hurcd11\&div=180\&id=\&page=> (2021, January, 12).
} 
correlates with the procedure in the court of first instance and whether the appellate court will be able to correct omission made by the court of first instance if necessary.

In the case of BERARU v. ROMANIA applicant, alleged a violation of Art. 6 (1) in conjunction with Art. 6 (3) b, 6 (3) c, 6 (3) d of the Convention. The applicant, in particular, complained about the limited access to the case file, which was essentially part of the "facilities" provided for in Art. 6 (3) b of the Convention. The Court reiterated that unrestricted access to case materials and the ability to use notes, including, if necessary, the possibility of obtaining copies of relevant documents, is important guarantees of a fair trial. Restriction of such access indicates a violation of the principle of equality of arms.

The circumstances of the case show that the applicant's lawyers were unable to gain direct access to the case file until later stages. From the outset, the applicant and his lawyers were not provided with a copy of the indictment. When the applicant's lawyers applied for permission to photocopy the documents in the case, their request was initially denied without justification, the refusal was later explained by the lack of equipment, and the lawyers were asked to prepare handwritten notes.

The lawyers noted that the materials took up four hundred pages and were available for review only four hours a day, while the hearings was scheduled in four business days from that date. The Tribunal, in turn, provided lawyers with limited additional time to review documents and the opportunity to make up to thirty pages of photocopies from the materials. Moreover, they were unable to obtain either a copy of the transcript of the wiretapped recordings or a copy of the recorded telephone calls used as evidence in the case.

In view of the circumstances, the applicant's representatives tried to withdraw their representation due to the ineffectiveness of the defence. Having assessed the circumstances of the case, the Court confirmed that it was the lack of access to the case file, which caused difficulties in preparing the defence position, that was the reason for the lawyers' attempts to withdraw the above-mentioned representation.

The Court concluded that there had been a violation of the right to adequate time and facilities for the defence to prepare a defence position together with the guarantees provided for in Art. 6 (1), 6 (3) of the Convention ${ }^{1}$.

Thus, national courts and prosecution need to pay attention to the importance of providing sufficient facilities not only to the accused but also to his representative, particularly with regard to access to the case file, obtaining photocopies from the casefile in appropriate terms that will give the chance to examine the documents and prepare a position of defence.

\section{Concluding Remarks}

The above practice highlights several important points regarding the right of the accused to have adequate time and facilities to prepare his/her defence, in particular:

-this right extends not only to the suspect and the accused but also to his lawyers;

- most often the violation of this right indicates a violation of the principle of equality of arms;

-in most cases, this right is violated in conjunction with other rights under Art 6(1) and Art. 6 (3) of the Convention.

The analysis of the case law of the ECHR allows to identify which criteria (conditions) must be taken into account by national courts in order to respect for the right provided for in Art. 6 (3) b of the Convention effectively. Thus, the courts during decision making must consider, in particular, the following conditions that may affect the above mentioned right of the defence:

- awareness of the accused about the full content of the charge, the information on the charges' change, bringing this information by the prosecutor's office to the defence and the time provided for review and preparation of the defence position with regard to such changes in initial charge;

- submission of new documents by the prosecution just before the court hearing and awareaness of the defence about the content of such documents;

-the fact of acquaintance with the case materials during the previous proceedings, acquaintance with the materials by the applicant's lawyers, the way the applicant describes the circumstances in documents, which may or not testify to the applicant's awareness of the details of the case file;

-the existence of a conflict of interest between co-accused represented by one counsel, the applicant's statements during both the trial court and the appellate court (or the absence of expected statements);

- the possibility for the applicant to raise the issue of violation of his right in the appellate court and the possibility for the appellate court to fix the shortcomings of the trial in the court of first instance;

\footnotetext{
${ }^{1}$ European Court of Human Rights (2014). Beraru v. Romania, 40107/04 <https://sip.lex.pl/orzeczenia-i-pisma-urzedowe/ orzeczenia-sadow/40107-04-beraru-v-rumunia-wyrok-europejskiego-trybunalu-521529817> (2021, January, 12).
} 
-the length of the pre-trial stage, the time between detention and trial, the time provided to lodge the motion, and the time to question witnesses;

-the correlation of time intervals between the moment of materials' submission to the court and the actual consideration of the case and the speed of the trial, the possibility of witnesses' involvement;

-the sharp change in the expert's opinion (if any) can also affect the accused's right to sufficient facilities to prepare his defence;

- equal opportunities to personal participation in the court hearing, obtaining information about the date and place of its holding, especially when the prosecution enjoys such a chance;

-the availability of legal aid, the applicant's and his lawyers' ability to gain the direct access to the case file in due course;

-the impact of the applicant's transportation and detention conditions at the court building on his ability to prepare his defence;

- the presence of excessive control by the prosecution in the case of detention and the real possibility of confidential communication with defence counsel without the need to obtain unreasonable additional permission;

-the presence of restrictions imposed on the number and length of lawyers' visits;

-the presence of control under correspondence between the accused and his / her lawyers.

\section{References:}

1. Council of Europe, European Court of Human Rights (2018). Guide on Article 6 of the European Convention on Human Rights Right to a fair trial (criminal limb), 365-366. [in English].

2. European Court of Human Rights (1992). Hadjianastassiou v. Greece, $12945 / 87<\mathrm{https} / / /$ sip.lex.pl/orzeczeniai-pisma-urzedowe/orzeczenia-sadow/12945-87-hadjianastassiou-v-grecja-rezolucja-komitetu-521829056> (2021, January, 12). [in English].

3. European Court of Human Rights (1996). Domenichini v. Italy, 15943/90 $<$ https://www.refworld.org/cases,ECHR,3ae6b6d810.html> (2021, January, 12). [in English].

4. European Court of Human Rights (1998). Twalib v. Greece, 24294/94 $<$ https://www.tandfonline.com/doi/abs/10.1080/13642989808406777?journalCode=fjhr20 > (2021, January, 12). [in English].

5. European Court of Human Rights (1999). Pélissier and Sassi v. France, 25444/94, 62 $<$ https://www.legal-tools.org/doc/c7f9e0/pdf/> (2021, January, 12). [in English].

6. European Court of Human Rights (2000). Mattoccia v. Italy, 23969/94, 61 $<$ https://www.menschenrechte.ac.at/orig/00_4/Mattoccia.pdf $>$ (2021, January, 12). [in English].

7. European Court of Human Rights (2000). Zoon v. the Netherlands, 29202/95 $<$ https://heinonline.org/HOL/LandingPage?handle=hein.journals/hurcd11\&div=180\&id=\&page=> (2021, January, 12). [in English].

8. European Court of Human Rights (2002). G.B. v. France, 44069/98, $60<\mathrm{https}: / /$ cambodia.ohchr.org/sites/default/ files/echrsource/G.B.\%20v.\%20France\%20[2\%20Oct\%202001]\%20[EN].pdf> (2021, January, 12). [in English].

9. European Court of Human Rights (2005). Öcalan v. Turkey, 46221/99, 148 $<$ https://hudoc.echr.coe.int/fre\#\{"itemid":["001-69022"]\}> (2021, January, 12). [in English].

10. European Court of Human Rights (2008). Galstyan v. Armenia, 26986/03, $86<$ https://laweuro.com/?p=985> (2021, January, 12). [in English].

11. European Court of Human Rights (2009). Abramyan v. Russia, 10709/02 $<$ https://hudoc.echr.coe.int/fre\#\{"itemid":["001-155161"]\}> (2021, January, 12). [in English].

12. European Court of Human Rights (2009). Moiseyev v. Russia, 62936/00 <https://sip.lex.pl/orzeczenia-i-pismaurzedowe/orzeczenia-sadow/62936-00-moiseyev-v-rosja-decyzja-europejskiego-520596694> (2021, January, 12). [in English].

13. European Court of Human Rights (2009). Tadevosyan v. Armenia, 41698/04 <https://sip.lex.pl/orzeczenia-i-pismaurzedowe/orzeczenia-sadow/41698-04-tadevosyan-v-armenia-wyrok-europejskiego-520562115> (2021, January, 12). [in English].

14. European Court of Human Rights (2013). Vyerentsov v. Ukraine, 20372/11, 76. $<$ https://www.conjur.com.br/dl/decisao-corte-europeia-ucrania.pdf $>$ (2021, January, 12). [in English].

15. European Court of Human Rights (2014). Beraru v. Romania, 40107/04 <https://sip.lex.pl/orzeczenia-i-pismaurzedowe/orzeczenia-sadow/40107-04-beraru-v-rumunia-wyrok-europejskiego-trybunalu-521529817> (2021, January, 12). [in English].

16. European Court of Human Rights (2018). Lambin v. Russia, 12668/08 $<$ https://www.bailii.org/eu/cases/ECHR/2017/1021.html> (2021, January, 12). [in English]. 